\title{
Multivariate analyses of fatty acid data from whole-cell methanolysates of Prevotella, Bacteroides and Porphyromonas spp.
}

\author{
Ilia Brondz, ${ }^{*}+$ Ingar Olsen, ${ }^{2}$ Markus HaApasalo ${ }^{3}$ and ARIE Jan Van WinkelhofF ${ }^{4}$ \\ ${ }^{1}$ Research Department, National Institute of Public Health, Umeå, Sweden \\ ${ }^{2}$ Department of Microbiology, Dental Faculty, University of Oslo, Oslo, Norway \\ ${ }^{3}$ Department of Cariology, University of Helsinki, Helsinki, Finland \\ ${ }^{4}$ Department of Oral Microbiology, Schools of Dentistry and Medicine, Free University, Amsterdam, The Netherlands
}

(Received 2 August 1990; revised 19 November 1990; accepted 13 February 1991)

\begin{abstract}
The genus Bacteroides contains a number of biochemically and physiologically heterogeneous groups of organisms and needs taxonomic revision. In this study cellular fatty acids from a number of Bacteroides spp. were identified and quantified using gas chromatography and gas chromatography-mass spectrometry. The chemical data were then subjected to principal components analysis. In $B$. fragilis, which is the type species of the genus Bacteroides, $\mathrm{C}_{3 . \mathrm{OH} \text {-iso } 17}$ was the predominant fatty acid (38.0\%) and $\mathrm{C}_{\text {ante1 } 15}$ was present in higher amounts $(32.7 \%)$ than $\mathrm{C}_{\text {isol } 15}$ $(14.6 \%)$. B. fragilis thus differed from all the other species examined: Prevotella (Bacteroides) buccae, $P$. (B.) oralis, $P$. (B.) oris, $P$. (B.) disiens, $P$. (B.) veroralis, $P$. (B.) heparinolytica and Porphyromonas (Bacteroides) endodontalis. Principal components analysis also enabled the closely related $P$. buccae, $P$. oralis and $P$. oris to be differentiated.
\end{abstract}

\section{Introduction}

Bacteroides species are obligately anaerobic, Gramnegative, non-motile and motile rods commonly encountered in polymicrobial infections at various sites in humans and animals, including the oral cavity, the urinary, gastrointestinal and respiratory tracts, and postsurgical wounds (Finegold \& George, 1989). Due to their major role in anaerobic infections of these sites, Bacteroides species have been under intensive study in recent years.

According to the Approved Lists of Bacterial Names (Moore et al., 1985), the genus Bacteroides comprises more than 50 species and has been used continuously as a repository for a varied collection of obligately anaerobic, Gram-negative, non-sporing, rod-shaped bacteria (Shah $\&$ Collins, 1989). Therefore, this genus now contains biochemically and physiologically heterogeneous groups of organisms and is in need of taxonomic revision. Some efforts have been made already to achieve this. Several Bacteroides species have been proposed to have separate generic status, e.g. Anaerorhabdus for B. furcosus (Shah \&

$\dagger$ Present address: Norwegian Plant Protection Institute, Box 70, N-1432 Ås-NLH, Norway.

Abbreviation: PCA, principal components analysis.
Collins, 1986); Megamonas for B. hypermegas (Shah \& Collins, 1982a); Mitsuokella for B. multiacidus (Shah \& Collins, 1982b); Porphyromonas for B. asaccharolyticus, $B$. endodontalis and B. gingivalis (Shah \& Collins, 1988); Rikenella for B. microfusus (Collins et al., 1985); Sebaldella for B. termiditis (Collins \& Shah, 1986a); Tissierella for B. praeacutus (Collins \& Shah, 1986 b); and Prevotella for $B$. melaninogenicus, $B$. oralis and related species (Shah \& Collins, 1990).

There is biochemical, chemical and molecular biological evidence that the genus Bacteroides should be restricted to the type species $B$. fragilis and closely related organisms such as $B$. caccae, $B$. distasonis, $B$. eggerthii, $B$. merdae, $B$. ovatus, $B$. stercoris, $B$. thetaiotaomicron, $B$. uniformis and B. vulgatus (Collins \& Shah, 1987; Shah \& Collins, 1989). The $B$. fragilis group has a narrow $G+C$ range and is biochemically and taxonomically homogeneous (Shah \& Collins, 1983; Collins \& Shah, 1987). Also, rRNA homology studies have shown that $B$. fragilis and related species are coherent and distinct from other Bacteroides species (Johnson \& Harich, 1986).

In the past, the genus Bacteroides was frequently speciated according to the production of pigmented colonies on blood agar, its sugar fermentative ability, and the sensitivity to bile. However, the patterns of fatty acids, polar lipids and isoprenoid quinones may also 
Table 1. List of organisms investigated

\begin{tabular}{|c|c|c|c|}
\hline Species & Strain* & Sample no. & Isolated from: \\
\hline \multicolumn{4}{|c|}{$\begin{array}{l}\text { Non-pigmented } \\
\quad \text { Prevotella (Bacteroides) }\end{array}$} \\
\hline \multirow[t]{4}{*}{ buccae } & ES9-1 & 1 & Dental root canal \\
\hline & ES12-B & 2 & Dental root canal \\
\hline & ES17-1 & 3 & Dental root canal \\
\hline & $\operatorname{ATCC} 33574^{\mathrm{T}}$ & 6 & Gingival sulcus \\
\hline \multicolumn{4}{|c|}{ Prevotella (Bacteroides) } \\
\hline \multirow[t]{4}{*}{ oris } & ES14B-3A & 4 & Dental root canal \\
\hline & ES9-3 & 5 & Dental root canal \\
\hline & ES7-B0 & 7 & Dental root canal \\
\hline & $\operatorname{ATCC} 33573^{\mathrm{T}}$ & 8 & Gingival sulcus \\
\hline \multicolumn{4}{|c|}{ Prevotella (Bacteroides) } \\
\hline \multirow[t]{3}{*}{ oralis } & ESB4-B & 9 & Dental root canal \\
\hline & ES14B-1B & 10 & Dental root canal \\
\hline & ES15-2 & 11 & Dental root canal \\
\hline \multicolumn{4}{|c|}{ Prevotella (Bacteroides) } \\
\hline disiens & DSM $20516^{\mathrm{T}}$ & 12 & Bartholin abscess \\
\hline \multicolumn{4}{|c|}{ Prevotella (Bacteroides) } \\
\hline veroralis & ATCC $33779^{\top}$ & 13 & Oral cavity \\
\hline \multicolumn{4}{|c|}{ Prevotella (Bacteroides) } \\
\hline heparinolytica & ATCC $35895^{\mathrm{T}}$ & 14 & Periodontal pocket \\
\hline Bacteroides fragilis & $\operatorname{ATCC} 25285^{\mathrm{T}}$ & 15 & Appendix abscess \\
\hline \multicolumn{4}{|l|}{ Pigmented } \\
\hline \multicolumn{4}{|c|}{ Porphyromonas (Bacteroides) } \\
\hline \multirow[t]{4}{*}{ endodontalis } & HG 412 & 16 & Dental root canal \\
\hline & HG $370^{\mathrm{T}}\left(\mathrm{ATCC} 35406^{\mathrm{T}}\right)$ & 17 & Dental root canal \\
\hline & HG 182 (BN 11a-f) & 18 & Dental root canal \\
\hline & HG 181 (H 11a-e) & 19 & Dental root canal \\
\hline
\end{tabular}

* ES, phenotypically characterized by M. Haapasalo; ATCC, American Type Culture Collection, Rockville, Md., USA; DSM, German Collection of Micro-organisms and Tissue Cultures, Braunschweig, FRG; HG, characterized by Van Winkelhoff et al. (1985); T, type strain.

assist in rationalizing the systematics of these organisms (for a review, see Wilkinson, 1988).

The present study, applying principal components analysis of fatty acid data from whole cells, was undertaken in an attempt to clarify further the inter- and intrageneric relationships of Bacteroides. Gas chromatographic (GC) and gas chromatographic-mass spectrometric (GC-MS) analyses of the cellular fatty acid composition are generally accepted as suitable and reliable methods in microbial chemotaxonomy (Brondz \& Olsen, 1986; Lechevalier \& Lechevalier, 1988). We have previously used multivariate analyses of cellular fatty acid data, obtained through GC and GC-MS analyses, to define genera of bacteria and yeasts such as Porphyromonas (Brondz et al., 1989a), Actinobacillus, Haemophilus and Pasteurella (Brondz et al., 1990), Treponema (Brondz et al., 1991), and Candida, Torulopsis and Saccharomyces (Brondz et al., 1989b; Brondz \& Olsen, 1990).

\section{Methods}

Organisms and growth conditions. Bacterial strains used in this study are listed in Table 1 . The reference strains were obtained directly from the American Type Culture Collection (ATCC) or the German Collection of Micro-organisms and Tissue Cultures (DSM), except Prevotella (Bacteroides) heparinolytica which was received from Dr K. Okuda, Tokyo Dental College, Tokyo, Japan, $P$. (B.) veroralis, which was sent to us by Dr H. N. Shah, London Hospital Medical College, London, UK, and Porphyromonas (Bacteroides) endodontalis strains HG 181 and 182, which were received from Dr G. Sundquist, University of Umeå, Umeå, Sweden. All clinical isolates were from necrotic root canals (Sundquist, 1976; Van Steenbergen et al., 1984; Van Winkelhoff et al., 1985; Haapasalo, 1986). For fatty acid analyses, the organisms were grown for $2-5 \mathrm{~d}$ at $37^{\circ} \mathrm{C}$ under anaerobic conditions in Mycoplasma broth (BBL) supplemented with menadione $\left(0.5 \mathrm{mg} \mathrm{l}^{-1}\right)$, haemin $\left(5 \mathrm{mg} \mathrm{l}^{-1}\right)$ and cysteine $\left(0.5 \mathrm{~g} \mathrm{l}^{-1}\right)$, harvested by centrifugation, washed in distilled water, and lyophilized.

Methanolysis and derivatization. Lyophilized whole cells were methanolysed with $2 \mathrm{M}-\mathrm{HCl}$ in anhydrous methanol for $24 \mathrm{~h}$ at $95^{\circ} \mathrm{C}$ (Brondz \& Olsen, 1984b). Excess methanol/ $\mathbf{H C l}$ was evaporated with a stream of $\mathrm{N}_{2}$ in an ice-bath and the methanolysate was then extracted 
with $\mathrm{n}$-hexane. $\mathrm{HCl}$, methanol and $\mathrm{n}$-hexane were obtained from $\mathrm{E}$. Merck. The above procedure was used for routine examination of fatty acid contents. For assessment of hydroxy fatty acids, the hydroxy groups were derivatized with trifluoroacetic acid anhydride. This was done in a $7: 3(\mathrm{v} / \mathrm{v})$ mixture of acetonitrile (Rathburn Chemicals) and trifluoroacetic acid anhydride (Fluka Chemie) at $90{ }^{\circ} \mathrm{C}$ for $3 \mathrm{~min}$. Before GC the solution was diluted with acetonitrile so that it contained $10 \%$ trifluoroacetic acid anhydride.

GC and GC-MS. A model 8700 gas chromatograph (Perkin Elmer) was used for fatty acid analyses. The column was an HP Ultra $1,25 \mathrm{~m}$ $\times 0.20 \mathrm{~mm}$ i.d. Helium was the carrier gas, at a flow rate of $1.5 \mathrm{ml}$ $\min ^{-1}$. The temperature of the injector was $200^{\circ} \mathrm{C}$, and the temperature of the flame-ionization detector was $275^{\circ} \mathrm{C}$. The programme was as follows: the temperature was held for 1 min at $90^{\circ} \mathrm{C}$ and then rose from $90^{\circ} \mathrm{C}$ to $275^{\circ} \mathrm{C}$ at a rate of $6{ }^{\circ} \mathrm{C} \mathrm{min}-1$. The attenuator was set at 16 . Paper speed was $5 \mathrm{~mm} \mathrm{~min}^{-1}$. The sample $(0.2 \mu \mathrm{l})$ was delivered as a splitless injection. The identities of the methanolysed and methanolysed and derivatized fatty acids were established by direct co-chromatography with authentic standards and by GC-MS (Brondz \& Olsen, 1984b; 1985). From each duplicate sample two independent derivatizations were made, and three injections were made from each of the latter. The quantity of the substances, expressed as the relative percentage, was calculated from the area under each peak and corrected with the molar response factor (Brondz \& Olsen, 1984b). The sum of the identified substances was considered to be $100 \%$. For identification of fatty acids, methyl ester standards of decanoic, dodecanoic, tetradecanoic, pentadecanoic, hexadecanoic and octadecanoic acids were obtained from Sigma. Bacterial acid methyl esters mixture $\mathrm{CP}$, gas-liquid chromatography standard mixture GLC 70, American Oil Chemists' Society oil reference mixture, RM-1 rapeseed, National Institutes of Health reference mixtures and FA-FAME kit 14 were obtained from Supelco. 13-Methyltetradecanoic acid methyl ester, methyl-12-methyltetradecanoic acid ester, methyl-14-methylhexadecanoic acid ester, methyl14-methylpentadecanoic acid ester, methyl-15-methylhexadecanoic acid ester and methyl-11-methyltridecanoic acid ester were from Larodan Fine Chemicals. Phenol/water extracted lipopolysaccharides from Porphyromonas (Bacteroides) gingivalis ATCC $33277^{\mathrm{T}}$ (Brondz et al., 1989a) and Actinobacillus (Haemophilus) actinomycetemcomitans ATCC $33384^{\mathrm{T}}$ (Brondz \& Olsen, $1984 a$ ) were also used as standards for identification of fatty acids.

Statistical analyses. Principal components analysis (PCA) (Joliffe, 1986; Wold et al., 1987) was used for quantitative analysis of fatty acid data. With this method the original space for variable measurements was projected down onto two low-dimensional subspaces. One of these was sample-related, the other was variable-related. By plotting the sample-oriented parameters $t_{1}$ versus $t_{2}$, information on the dominating behaviour of the samples was gained, and by plotting the variable loadings $p_{1}$ versus $p_{2}$, information was obtained on which variables contributed to the corresponding sample-oriented projection. The complexity and stability of both models was determined by crossvalidation (Wold, 1976, 1978).

\section{Results}

\section{$G C$ and $G C$-MS analyses}

The distribution of fatty acids in whole-cell methanolysates from the non-pigmented and pigmented species tested is shown in Table 2. Thirteen different fatty acids including normal fatty acids, saturated fatty acids, iso- and anteisobranched fatty acids and hydroxy fatty acids were detected. Unsaturated fatty acids were not found. It was noteworthy that $B$. fragilis, the type species of the genus Bacteroides, differed from all other species examined by having 3-hydroxy-15-methylhexadecanoic acid $\left(\mathrm{C}_{3-\mathrm{OH}-\text {-iso1 } 7}\right)$ as the predominant acid. Further, the 12-methyltetradecanoic acid $\left(\mathrm{C}_{\text {ante15 }}\right)$ content was greater than the 13-methyltetradecanoic acid $\left(\mathrm{C}_{\mathrm{iso} 15}\right)$ content in this organism. Other characteristic findings were as follows: in most saccharoclastic, non-pigmented organisms [Prevotella (Bacteroides) buccae, $P$. (B.) oris, $P$. (B.) oralis, $P$. (B.) veroralis and $P$. (B.) disiens] 12methyltetradecanoic acid was the predominant fatty acid, whereas in asaccharoclastic, black-pigmented organisms [Porphyromonas (Bacteroides) endodontalis] and in the saccharoclastic, non-pigmented Prevotella (Bacteroides) heparinolytica, 13-methyltetradecanoic acid predominated. Porphyromonas (Bacteroides) endodontalis, Prevotella (Bacteroides) heparinolytica, and, as mentioned, $B$. fragilis, contained large amounts of 3-hydroxy15-methylhexadecanoic acid. Whereas 13-methyltetradecanoic acid constituted a significant portion of the cellular fatty acids in Prevotella (Bacteroides) oris, the content was much lower in $P$. (B.) buccae and $P$. (B.) oralis. $P$. oralis seemed to have a higher content of hexadecanoic $\left(C_{16: 0}\right)$ acid than the other organisms.

\section{Statistical analyses}

In the PCA, the two principal score vectors, $t_{1}$ and $t_{2}$ were plotted against each other (Fig. 1). This sampleoriented (i.e. bacterial-strain-oriented) projection described the two largest variants of the data matrix in Table 2. The two principal components, $t_{1}$ and $t_{2}$, accounted for $33.1 \%$ and $26.4 \%$, respectively, of the variance. In this projection, Prevotella (Bacteroides) buccae (samples 1, 2, 3 and 6) and $P$. (B.) oralis (samples 9, 10 and 11) constituted two overlapping groups of organisms. $P$. (B.) oris (samples 4,57 and 8), $P$. (B.) heparinolytica (sample 14), $P$. (B.) disiens (sample 12) and $P$. (B.) veroralis (sample 13) were distinct from $P$. $(B$.) buccae and $P$. (B.) oralis. Porphyromonas (Bacteroides) endodontalis (samples 16, 17, 18 and 19) formed a homogeneous cluster distinct from the remaining species examined.

The first and the third principal score vectors, $t_{1}$ and $t_{3}$, were also plotted against each other (Fig. 2). This sample-oriented projection described the largest and the third largest variant of the data matrix, constituting $33.1 \%$ and $11.0 \%$, respectively, of the variance. In this projection there was a possible separation of Prevotella (Bacteroides) buccae (samples 1, 2, 3 and 6) and $P$. (B.) oralis (samples 9, 10 and 11), but no definite conclusion 


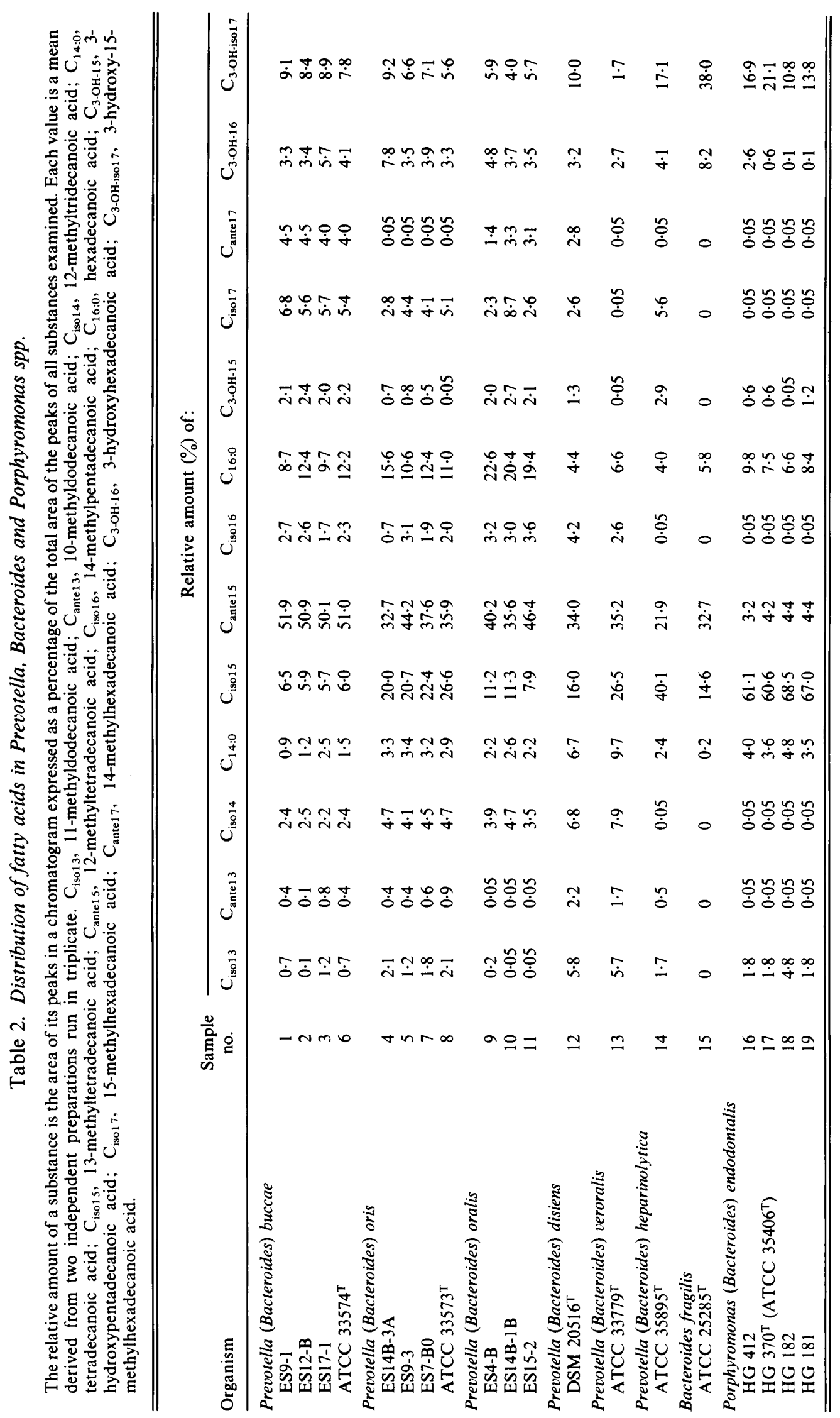




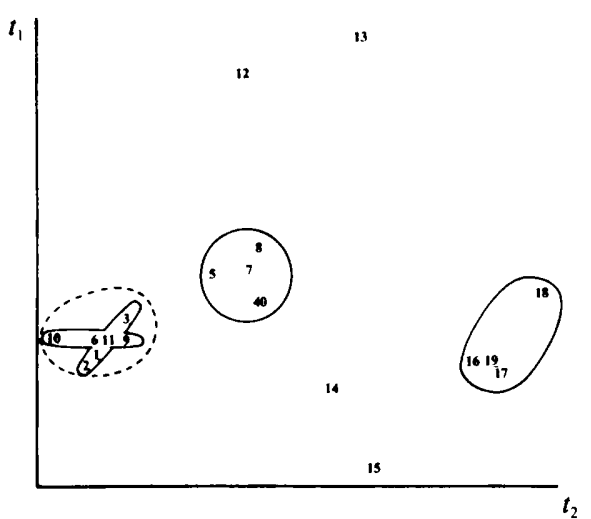

Fig. 1

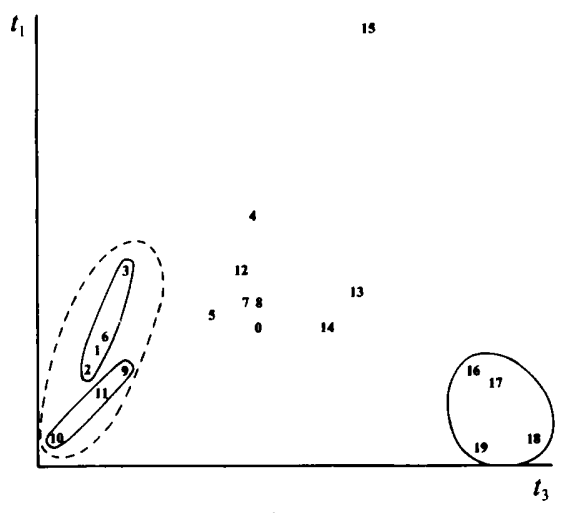

Fig. 2

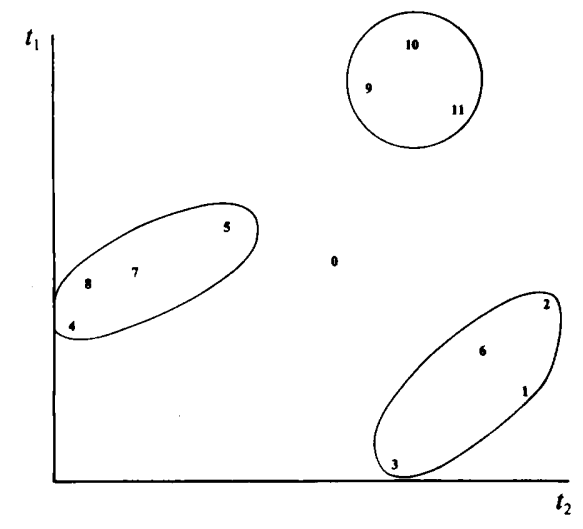

Fig. 3

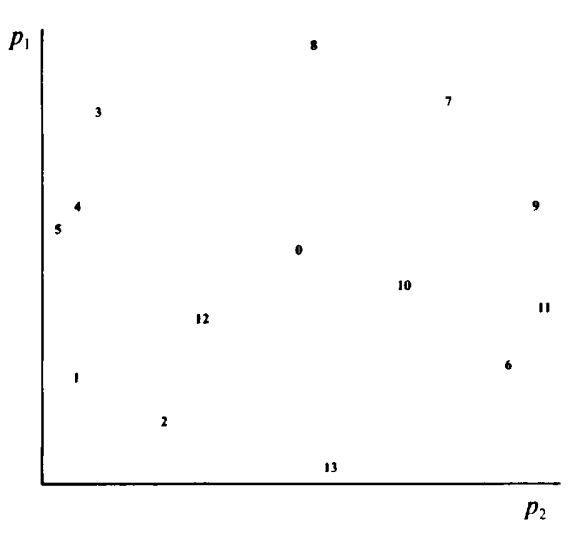

Fig. 4

Fig. 1. Sample-oriented (i.e. bacterial-strain-oriented) principal components projection $\left(t_{1}\right.$ versus $\left.t_{2}\right)$. These two principal components describe $33.1 \%$ and $26.4 \%$, respectively, of the variance of the data in Table 2. Samples include : Prevotella (Bacteroides) buccae (samples $1,2,3$ and 6), $P$. (B.) oris (samples 4, 5, 7 and 8), $P$. (B.) oralis (samples 9,10 and 11), $P$. (B.) disiens (sample 12), $P$. (B.) veroralis (sample 13), P. (B.) heparinolytica (sample 14), B. fragilis (sample 15) and Porphyromonas (Bacteroides) endodontalis (samples 16, 17, 18 and 19). A complete line (-) surrounds samples representing the same species; closely related species are surrounded by a dashed line (- - ).

Fig. 2. Sample-oriented principal components projection $\left(t_{1}\right.$ versus $\left.t_{3}\right)$. These two principal components describe $33 \cdot 1 \%$ and $11 \cdot 1 \%$, respectively, of the variance of the data in Table 2. Sample numbers are as in Fig. 1. A complete line (-) surrounds samples representing the same species; closely related species are surrounded by a dashed line (- - ).

Fig. 3. Sample-oriented principal components projection $\left(t_{1}\right.$ versus $\left.t_{2}\right)$. These two principal components describe $38.0 \%$ and $24 \cdot 3 \%$, respectively, of the variance in the data (Table 2 ) related exclusively to $P$. (B.) buccae, $P$. (B.) oris and $P$. (B.) oralis. Sample numbers representing these species are as in Fig. 1.

Fig. 4. Variable-oriented (i.e. bacterial-character-oriented) principal components projection $\left(p_{1}\right.$ versus $\left.p_{2}\right)$. The numbers refer to the following variables (Table 2): 1, 11-methyldodecanoic acid $\left(C_{\text {iso 13 }}\right) ; 2,10$-methyldodecanoic acid $\left(C_{\text {ante 13 }}\right) ; 3,12$-methyltridecanoic acid $\left(C_{\text {isol } 14}\right) ; 4$, tetradecanoic acid $\left(C_{14: 0}\right) ; 5,13$-methyltetradecanoic acid $\left(C_{\text {isol } 15}\right) ; 6,12$-methyltetradecanoic acid $\left(C_{\text {ante15 }}\right)$; $7,14-$ methylpentadecanoic acid $\left(\mathrm{C}_{\text {iso16 }}\right)$; 8, hexadecanoic acid $\left(\mathrm{C}_{16: 0}\right) ; 9$, 3-hydroxypentadecanoic acid $\left(\mathrm{C}_{3-\mathrm{OH}-15}\right)$; 10, 15-methylhexadecanoic acid $\left(\mathrm{C}_{\text {iso17 }}\right)$; 11, 14-methylhexadecanoic acid $\left(\mathrm{C}_{\text {ante17 }}\right)$; 12, 3-hydroxyhexadecanoic acid $\left(\mathrm{C}_{3-\mathrm{OH}-16}\right)$; and 13, 3-hydroxy-15methylhexadecanoic acid $\left(\mathrm{C}_{3 . \mathrm{OH} \text {-iso 1 } 7}\right)$. It can be seen from the plot that the variables that contribute most to the first score vector $\left(t_{1}\right)$ are variables 13 and 8 , and those variables that contribute most to the second score vector $\left(t_{2}\right)$ are variables $1,3,5,4,9$ and 6 . (See text for description of method.)

could be made. Separation of the other species examined, however, remained distinct. B. fragilis was distant from species proposed to belong to Porphyromonas (Shah \& Collins, 1988) and Prevotella (Shah \& Collins, 1990).

To determine whether $P$. (B.) buccae, $P$. (B.) oris and $P$. $(B$.$) oralis really differed in their fatty acid contents, a$ PCA was done exclusively for these species. In the sample-oriented projection shown in Fig. 3 the two largest variants, $t_{1}$ and $t_{2}$, described $38.0 \%$ and $24.3 \%$, respectively, of the variance in the fatty acid data (Table 2 ) from these species. This projection provided a clear separation between $P$. (B.) buccae (samples 1, 2, 3 and 6), $P$. (B.) oris (samples 4, 5, 7 and 8 ) and $P$. (B.) oralis (samples 9, 10 and 11). 
The variables (i.e. bacterial characters, Table 2) that contributed most to the first score vector $\left(t_{1}\right)$ were those with high absolute loading values, namely variable 13 (3hydroxy-15-methylhexadecanoic acid) and variable 8 (hexadecanoic acid) (Fig. 4). Those variables that contributed most to the second score vector $\left(t_{2}\right)$ were variables 1 (11-methyldodecanoic acid), 3 (12-methyltridecanoic acid), 5 (13-methyltetradecanoic acid), 4 (tetradecanoic acid), 11 (14-methylhexadecanoic acid), 9 (3-hydroxypentadecanoic acid) and 6 (12-methyltetradecanoic acid).

\section{Discussion}

The present study, which used PCA of cellular fatty acid data, has provided new information on the intrageneric and intergeneric relationships of Bacteroides. The fatty acid content of the bile-resistant, non-pigmented $B$. fragilis was similar to that reported previously (Brondz et al., 1989a). B. fragilis was the only species where the $\mathrm{C}_{3-\mathrm{OH}-\mathrm{iso1} 1}$ acid dominated and the $\mathrm{C}_{\text {ante15 }}$ acid content was higher than that of the $\mathrm{C}_{\text {iso } 15}$ acid and is thus entirely different from the other species examined. The present findings support the proposal that $B$. fragilis and closely related species, should form the genus Bacteroides sensu stricto (Collins \& Shah, 1987; Shah \& Collins, 1989).

Whereas asaccharoclastic, black-pigmented organisms, as represented by Porphyromonas (Bacteroides) endodontalis, contained large amounts of 13-methyltetradecanoic acid $\left(\mathrm{C}_{\text {isol } 5}\right)$, most saccharoclastic, bile-sensitive, non-pigmented species [Prevotella (Bacteroides) buccae, $P$. (B.) oris, $P$. (B.) oralis, $P$. (B.) disiens and $P$. (B.) veroralis] had 12 -methyltetradecanoic acid $\left(\mathrm{C}_{\text {ante15 }}\right)$ as the predominant fatty acid. Asaccharoclastic, blackpigmented organisms also tended to contain more 3hydroxy-15-methylhexadecanoic acid $\left(\mathrm{C}_{3-\mathrm{OH}-\text {-isol } 7}\right)$ than did saccharoclastic, non-pigmented species with the exception of $P$. (B.) heparinolytica and $B$. fragilis. This supported the proposed distinction between the Bacteroides-derived genera Porphyromonas (Shah \& Collins, 1988) and Prevotella (Shah \& Collins, 1990). The fatty acid profile of Porphyromonas (Bacteroides) endodontalis was quite similar to that reported previously for $P$. (B.) endodontalis, $P$. (B.) gingivalis and $P$. (B.) asaccharolytica (Brondz et al., 1989a). Multivariate fatty acid analyses have also distinguished Porphyromonas species from other black-pigmented species such as Prevotella (Bacteroides) melaninogenica, $P$. (B.) intermedia and $B$. levii (Brondz et al., 1989a).

Prevotella (Bacteroides) heparinolytica differed from the other non-pigmented, bile-sensitive, saccharoclastic species by having 13-methyltetradecanoic acid as its major fatty acid. It also contained large amounts of 3- hydroxy-15-methylhexadecanoic acid, as did black-pigmented species. However, PCA of the fatty acid content confirmed that $P$. (B.) heparinolytica is distinct from asaccharolytic species. It has been established previously (Okuda et al., 1985) that there are no antigenic or serological relationships between $P$. (B.) heparinolytica and other Bacteroides species. The sole characteristic that reliably differentiated this species from other nonpigmented saccharoclastic Bacteroides species was its heparain-degrading activity. The present study suggested that multivariate cellular fatty acid analyses could also be useful for this distinction.

Very few criteria are available for taxonomic distinction between Prevotella (Bacteroides) buccae, $P$. (B.) oris and $P$. (B.) oralis (Holdeman et al., 1982, 1984). Enzyme patterns have been useful in differentiating these species (Holdeman et al., 1984; Haapasalo, 1986). Much confusion has existed as to the identification of $P$. (B.) oralis, and some strains previously referred to as $P$. (B.) oralis in the literature were, in fact, $P$. (B.) oris or $P$. (B.) buccae (Holdeman et al., 1984; Johnson \& Holdeman, 1985). B. pentosaceus and B. capillus appear to be synonyms of $P$. (B.) buccae (Holdeman et al., 1984; Johnson \& Holdeman, 1985). Further, it has been suggested that $P$. (B.) oralis is a non-pigmented variant of $B$. melaninogenica subsp. melaninogenica (Harding et al., 1976; Holbrook et al., 1977), P. (B.) loescheii has been identified as $P$. (B.) oralis or $P$. (B.) melaninogenica (Holdeman \& Johnson, 1982). The similarity of $P$. (B.) oralis strains to $P$. (B.) ruminicola has also been noted (Sundquist, 1976). P. (B.) veroralis is phenotypically quite similar to $P$. (B.) oralis (Watabe et al., 1983; Holdeman et al., 1984). Helpful phenotypic characteristics to differentiate these species have been fermentation of aesculin and salicin by $P$. (B.) oralis but not by $P$. (B.) veroralis (Holdeman et al., 1984). In the present study $P$. (B.) oralis and $P$. (B.) veroralis appeared to be clearly distinct. Our findings suggested that PCA of cellular fatty acids can assist in the differentiation of $P$. (B.) oralis from closely related species.

Identifying $P$. (B.) disiens may occasionally be problematic since this species has a sugar fermentation pattern quite similar to that of the black-pigmented $P$. (B.) corporis (Holdeman \& Johnson, 1977; Holdeman et al., 1984). Non-hydroxy straight-chain and branchedchain fatty acids in $P$. (B.) disiens were found by Mayberry (1980) to be similar to those in $P$. (B.) oralis. Multivariate fatty acid analyses (this study) show that $P$. $(B$.) disiens is clearly different from all the other Prevotella species examined.

We thank Norsk Dental Depot's Fond for Odontologisk Forskning, Tannlegeundervisningens Fond, and Nordisk Ministerråd (Nordisk forskarstipendium no. 035/90), for financial support. 


\section{References}

Brondz, I. \& OLSEN, I. (1984a). Differentiation between Actinobacillus actinomycetemcomitans and Haemophilus aphrophilus based on carbohydrates in lipopolysaccharide. Journal of Chromatography 310, 261272.

Brondz, I. \& OLSEN, I. (1984b). Whole-cell methanolysis as a rapid method for differentiation between Actinobacillus actinomycetemcomitans and Haemophilus aphrophilus. Journal of Chromatography 311, 347-353.

BRONDZ, I. \& OLSEN, I. (1985). Differentiation between major species of the Actinobacillus-Haemophilus-Pasteurella group by gas chromatography of trifluoroacetic acid anhydride derivatives from wholecell methanolysates. Journal of Chromatography 342, 13-23.

BRONDZ, I. \& OLSEN, I. (1986). Microbial chemotaxonomy. Chromatography, electrophoresis and relevant profiling techniques. Journal of Chromatography 379, 367-411.

BRONDZ, I. \& OLSEN, I. (1990). Multivariate analyses of cellular carbohydrates and fatty acids in Candida albicans, Torulopsis glabrata and Saccharomyces cerevisiae. Journal of Clinical Microbiology 28, 1854-1857.

Brondz, I., Carlsson, J., Suöström, M. \& Sundquist, G. (1989a). Significance of cellular fatty acids and sugars in defining the genus Porphyromonas. International Journal of Systematic Bacteriology 39, 314-318.

BRONDZ, I., OLSEN, I. \& SJÖSTRÖM, M. (1989b). Gas chromatographic assessment of alcoholyzed fatty acids from yeasts: a new chemotaxonomic method. Journal of Clinical Microbiology 27, 2815-2819.

BRONDZ, I., OLSEN, I. \& SJöSTRÖM, M. (1990). Multivariate analysis of quantitative chemical and enzymic characterization data in classification of Actinobacillus, Haemophilus and Pasteurella spp. Journal of General Microbinlogv 136. 507-513.

Brondz, I., FichN, N.-E., Olsen, I. \& SJöström, M. (1991). Multivariate analyses of cellular fatty acids and carbohydrates of $1: 2: 1$ and $2: 4: 2$ spirochetes. Acta Pathologica, Microbiologica et Immunologica Scandinavica 99, (in the Press).

Collins, M. D. \& SHAH, H. N. (1986a). Reclassification of Bacteroides termiditis Sebald (Holdeman and Moore) in a new genus Sebaldella, as Sebaldella termiditis comb. nov. International Journal of Systematic Bacteriology 36, 349-350.

Collins, M. D. \& SHAH, H. N. (1986b). Reclassification of Bacteroides praeacutus Tissier (Holdeman and Moore) in a new genus, Tissierella, as Tissierella praeacuta comb. nov. International Journal of Systematic Bacteriology 36, 461-463.

Collins, M. D. \& SHAH, H. N. (1987). Recent advances in the taxonomy of the genus Bacteroides. In Recent Advances in Anaerobic Bacteriology, pp. 249-258. Edited by S. P. Borrellio and others. Dordrecht, The Netherlands: Martinus Nijhoff.

Collins, M. D., Shah, H. N. \& MitsuoKa, T. (1985). Reclassification of Bacteroides microfusus (Kaneuchi and Mitsuoka) in a new genus Rikenella, as Rikenella microfusus comb. nov. Systematic and Applied Microbiology 6, 79-81.

Finegold, S. M. \& GeORGe, W. L. (1989). Anaerobic Infections in Humans. San Diego: Academic Press.

HaAPASAlo, M. (1986). Bacteroides buccae and related taxa in necrotic root canal infections. Infection and Immunity 53, 149-153.

Harding, G. K. M., SutTer, V. L., Finegold, S. M. \& Bricknell, K. S. (1976). Characterization of Bacteroides melaninogenicus. Journal of Clinical Microbiology 4, 354-359.

Holbrook, W. P., Duerden, B. I. \& Deacon, A. G. (1977). The classification of Bacteroides melaninogenicus and related species. Journal of Applied Bacteriology 42, 259-273.

Holdeman, L. V. \& Johnson, J. L. (1977). Bacteroides disiens sp. nov. and Bacteroides bivius sp. nov. from human clinical infections. International Journal of Systematic Bacteriology 27, 337-345.

Holdeman, L. V. \& Johnson, J. L. (1982). Description of Bacteroides loescheii sp. nov. and emendation of the descriptions of Bacteroides melaninogenicus (Oliver and Wherry) Roy and Kelly 1939 and Bacteroides denticola Shah and Collins 1981. International Journal of Systematic Bacteriology 32, 399-409.

Holdeman, L. V., Moore, W. E. C., Churn, P. J. \& Johnson, J. L. (1982). Bacteroides oris and Bacteroides buccae, new species from human periodontitis and other human infections. International Journal of Systematic Bacteriology 32, 125-131.

Holdeman, L. V., Kelley, R. W. \& MoORe, W. E. C. (1984). Genus I. Bacteroides Castellani and Chalmers 1919. In Bergey's Manual of Systematic Bacteriology, vol. 1, pp. 604-631. Edited by N. R. Krieg \& J. G. Holt. Baltimore: Williams \& Wilkins.

Johnson, J. L. \& HARICH, B. (1986). Ribosomal ribonucleic acid homology among species of the genus Bacteroides. International Journal of Systematic Bacteriology 36, 71-79.

Johnson, J. L. \& Holdeman, L. V. (1985). Bacteroides capillus Kornman and Holt and Bacteroides pentosaceus Shah and Collins, later synonyms of Bacteroides buccae Holdeman et al. International Journal of Systematic Bacteriology 35, 114.

Joliffe, I. T. (1986). Principal Component Analysis. New York: Springer-Verlag.

LeCHEVAlieR, H. \& LecheValier, M. P. (1988). Chemotaxonomic use of lipids - an overview. In Microbial Lipids, vol. 1, pp. 869-902. Edited by C. Ratledge \& S. G. Wilkinson. London: Academic Press.

MAYBERRY, W. R. (1980). Hydroxy fatty acids in Bacteroides species: D-( -)-3-hydroxy-15-methylhexadecanoate and its homologs. Journal of Bacteriology 143, 582-587.

MoOre, W. E. C., Cato, E. P. \& Moore, L. V. (1985). Index of the bacterial and yeast nomenclatural changes published in the International Journal of Systematic Bacteriology since the 1980 Approved Lists of Bacterial Names (1 January 1980 to January 1985). International Journal of Systematic Bacteriology 35, 382407.

OKuDa, K., Kato, T., Shiozu, J., Takazoe, I. \& Nakamura, T. (1985). Bacteroides heparinolyticus sp. nov. isolated from humans with periodontitis. International Journal of Systematic Bacteriology $35,438-442$.

SHAH, H. N. \& Collins, M. D. (1982a). Reclassification of Bacteroides hypermegas (Harrison and Hansen) in a new genus Megamonas, as Megamonas hypermegas comb. nov. Zentralblatt für Bakteriologie, Parasitenkunde, Infektionskrankheiten und Hygiene. (Abteilung I, Originale Reihe C) 3, 394-398.

SHAH, H. N. \& Collins, M. D. (1982b). Reclassification of Bacteroides multiacidus (Mitsuoka, Terada, Watanabe and Uchida) in a new genus Mitsuokella, as Mitsuokella multiacidus comb. nov. Zentralblatt für Bakteriologie, Parasitenkunde, Infektionskrankheiten und Hygiene (Abteilung I, Originale Reihe C) 3, 491-494.

Shah, H. N. \& Collins, M. D. (1983). Genus Bacteroides: a chemotaxonomic perspective. Journal of Applied Bacteriology 55, 403-416.

SHAH, H. N. \& Collins, M. D. (1986). Reclassification of Bacteroides furcosus Veillon and Zuber (Hauduroy, Ehringer, Urbain, Guillot and Magron) in a new genus Anaerorhabdus, as Anaerorhabdus furcosus comb. nov. Systematic and Applied Bacteriology 8, 86-88.

SHaH, H. N. \& Collins, M. D. (1988). Proposal for reclassification of Bacteroides asaccharolyticus, Bacteroides gingivalis, and Bacteroides endodontalis in a new genus, Porphyromonas. International Journal of Systematic Bacteriology 38, 128-131.

ShaH, H. N. \& Collins, M. D. (1989). Proposal to restrict the genus Bacteroides (Castellani and Chalmers) to Bacteroides fragilis and closely related species. International Journal of Systematic Bacteriology 39, 85-87.

ShaH, H. N. \& Collins, M. D. (1990). Prevotella, a new genus to include Bacteroides melaninogenicus and related species formerly classified in the genus Bacteroides. International Journal of Systematic Bacteriology 40, 205-208.

SUNDQUIST, G. (1976). Bacteriologic studies of necrotic dental pulps. Umeå University Odontological Dissertation no. 7, University of Umeå, Umeå, Sweden.

Van Steenbergen, T. J. M., Van Winkelhoff, A. J., Mayrand, D., Grenier, D. \& De GraAFF, J. (1984). Bacteroides endodontalis sp. nov., an asaccharolytic black-pigmented Bacteroides species from infected dental root canals. International Journal of Systematic Bacteriology 34, 118-120.

Van Winkelhoff, A. J., VAN SteEnbergen, T. J. M., KIPPUW, N. \& DE GraAfF, J. (1985). Further characterization of Bacteroides endodontalis, an asaccharolytic black-pigmented Bacteroides species from the oral cavity. Journal of Clinical Microbiology 22, 75-79. 
Watabe, J., Benno, Y. \& Mitsuoka, T. (1983). Taxonomic study of Bacteroides oralis and related organisms and proposal of Bacteroides veroralis sp. nov. International Journal of Systematic Bacteriology 33, $57-64$.

Wilkinson, S. G. (1988). Gram-negative bacteria. In Microbial Lipids, vol. 1, pp. 299-488. Edited by C. Ratledge \& S. G. Wilkinson. London: Academic Press.
Wold, S. (1976). Pattern recognition by means of disjoint principal components models. Pattern Recognition 8, 127-139.

WoLD, S. (1978). Cross-validatory estimation of the number of components in factor and principal components models. Technometrics 20, 397-405.

Wold, S., Esbendsen, K. \& Geladi, P. (1987). Principal component analysis. Chemometrics and Intelligent Laboratory Systems 2, 37-52. 